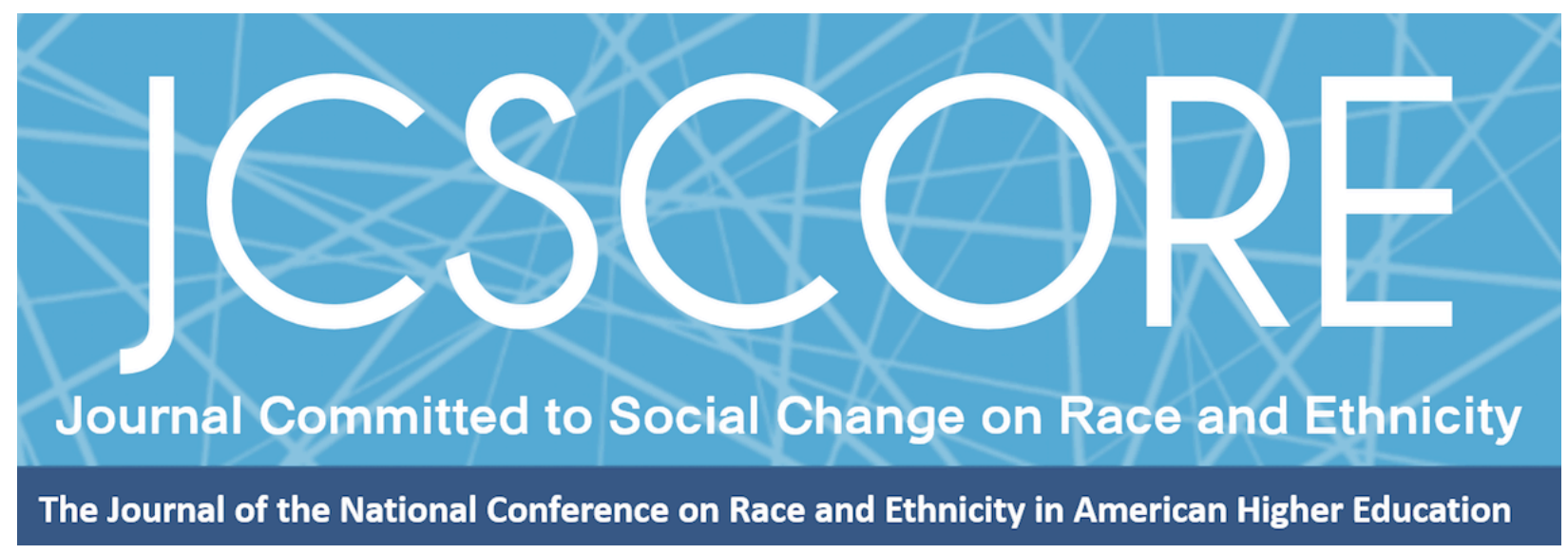

\title{
ENVISIONING POSSIBILITIES FOR INNOVATIONS IN HIGHER EDUCATION RESEARCH ON RACE AND ETHNICITY
}

\author{
D-L Stewart \\ Colorado State University
}

Journal Committed to Social Change on Race and Ethnicity

Volume 5, Issue 1 | 2019

Copyright @ 2019 Board of Regents of The University of Oklahoma on behalf of the Southwest Center for Human Relations Studies.

Permission of the Publisher is required for resale or distribution and for all derivative works, including compilations and translations. Quoting small sections of text is allowed as long as there is appropriate attribution. 


\title{
Envisioning Possibilities for Innovations in Higher Education Research on Race and Ethnicity
}

\author{
D-L Stewart \\ Colorado State University
}

This article uses the Sankofa principle of going back and getting that which can enable a community to imagine new possibilities. In this article, four waves of current research in race and ethnicity in higher education are offered, as well as some lessons learned from them. These considerations provide the backdrop for imagining how a fifth wave may be ontologically and epistemologically oriented, what themes it might take up, and its possible implications.

Among the Akan people of West Africa, the Sankofa bird whose head is turned backward with an egg in its mouth while its feet point forward, represents the importance of knowing one's history in order to move into the future. A community's failure to honor the lessons of its history risks a repeat of its failures. It is in the spirit of Sankofa that I offer some thoughts on how to move higher education research on race and ethnicity forward by first considering its history and the lessons I believe it offers researchers and practitioners today.

As I engage in this Sankofic exploration, I borrow the metaphor of waves from Jones and Stewart (2016). Jones and Stewart use the wave metaphor, themselves borrowing from feminist historiography, to trace the evolution of student development theory. Three aspects of the wave metaphor that Jones and Stewart enumerate are useful for the discussion in this paper. First, waves overlap each other. Consequently, the waves that I identify in this discussion, do not have discrete beginning and end points that follow each other. Second, waves are ongoing, at least until they crash into some obstacle or land(ing). Connected to the first point, the earliest of these waves 
Journal Committed to Social Change on Race and Ethnicity | 2019

continue into the present and likely will into the future. What land(ing) might cause them to crash, in my estimation, is yet to be determined. Third, all waves enable forward movement. Thus, my sequential numbering of these waves is not meant to signal hierarchy, nor is the numbering equated with value or worth. Each wave, in some way, has advanced theory and practice concerning race and ethnicity in U.S. higher education.

As I write this paper, I acknowledge how I use language regarding race and ethnicity. I recognize capitalization as a performative act that promotes and legitimates. Following Crenshaw (1991) and Perez Huber (2010), I do not capitalize white as a racial category. When generally speaking of minoritized racial and ethnic groups, I use the abbreviation BIPOC, which stands for Black, Indigenous, and People of Color (Zuroski, 2018), to acknowledge the specificity of Black and Indigenous experiences of racialization and settler colonialism. When warranted, I use my current understanding, as of the date of this publication, to name specific racialized groups and ethnicities under discussion. Language shifts quickly and so all members of these groups may not use these appellations either now or in the future. I use the term Latinx to be inclusive of people who are gender non-conforming (Salinas \& Lozano, 2017) unless the author I discuss did not use this term. Finally, I do not use Black and African American interchangeably. I do use Black as a pan-African descriptor for indigenous Africandescended peoples racialized as Black in the U.S. racial hierarchy. African American is a specific ethnic descriptor that does not interpellate all people of African descent either within or beyond the United States. 


\section{Waves of Higher Education Research on Race and Ethnicity}

The scope of this recounting of some waves of research and practice concerning race and ethnicity is meant to be neither exhaustive nor to be considered and used as a formal synthesis of the literature. That would indeed be a useful exercise and one that should be undertaken. As previously noted, my goal with this historical consideration is to provide a platform that supports the reimagining of higher education research on race and ethnicity that I take up in the latter half of this article. For each wave, I consider three areas. First, due to higher education's multidisciplinary roots, I characterize how race is defined and used and the disciplinary antecedent that most closely connects to those definitions and views. Second, I note some exemplars that illustrate the wave. Again the intent here is not to be exhaustive, but rather descriptive. Third, I discuss the defining characteristics, key themes, and ideas that are advanced by that wave. Fourth, I identify the effects of the scholarship of that wave on institutional policy and practice.

This discussion focuses on U.S. higher education scholarship on race and ethnicity. I believe this is justified by the uniqueness and foundational character of U.S. racial schema and processes of racialization as they have informed the development of U.S. higher education.

\section{A First Wave: Race Is}

The first wave I consider begins in the 1940s and 1950s, whether produced during that era or not. The greatest force of this wave seems to last well into the 1980s. In this scholarship, race is treated as an inherent ego identity and social condition, drawing on both psychological (Hurtado, 2019) and anthropological roots (Warren, 
Journal Committed to Social Change on Race and Ethnicity | 2019

2019), respectively. Examples from this wave include research on both faculty and students, though students predominate. Anderson (1993) discussed the investigation of Fred G. Wale, director of the Julius Rosenwald Fund, into whether northern white colleges would hire Black faculty. During this same period, Plaut (1954) and Zimbardo (1966) begin to study the admission and experiences of Black students on historically white campuses. Later-wave illustrations include the canonical scholarship of Joyce Fleming's (1984) Blacks in College and Walter Allen's (1992) "The Color of Success."

Defining characteristics. There are five defining characteristics of this wave. First, scholars of this wave generally concerned themselves with race, not ethnicity. Moreover, race was positioned as a binary of Black and white, with Black configured as a racial monolith that did not distinguish across ethnicity and immigration histories.

Their focus was primarily on institutional settings and the racial composition of faculty or student constituencies. Comparative studies of Black students' experiences in historically white and historically Black universities also featured heavily during this era (Fleming, 1984; Feagin, Vera, \& Imani, 1996; Zimbardo, 1966). These scholars studied the psychological effects on Black students of predominantly white environments, Black students' educational outcomes, and the ego strength and validation offered by historically Black colleges and universities (HBCUs). Quantitative methods and ethnographic approaches predominated, which reflects, respectively, the psychological and anthropological roots of the research during this wave.

Resulting effects. As a result of these foci, scholars provided empirical support for the existence and positive effects of HBCUs' educational mission during a time when Black students' enrollment in those institutions was slipping due to legislative 
Journal Committed to Social Change on Race and Ethnicity | 2019

desegregation (Allen \& Jewell, 2002). The research of this wave also served to document the migration of Black students across the racialized sectors of four-year higher education institutions. Finally, this research brought to the fore issues of campus climate at historically white institutions (HWls). In sum, the first wave of higher education scholarship on race and ethnicity established the need for administrators and scholars to understand and address the needs of Black students beyond the desegregation of white institutions.

\section{A Second Wave: Theory Proliferation}

The second wave I have identified enters in the 1960s and 1970s and maintained its greatest strength into the 1990s, though later examples are evident. Psychology still had a significant hold; research in this era again treated race as an immutable ego identity. The educative activism of the Civil Rights Movement followed by the Black Power, Chicano rights, and American Indian Movement era provided ideological fuel for the burgeoning ethnic studies field(s) that also had a strong influence on race and ethnic scholarship in higher education during this wave.

The scholarship of this era generally splits its focus between racial identity development and institutional conditions as informative for understanding the experiences of BIPOC. However, much of the early focus is still on Black students as a racial monolith. Some of the canonical scholarship of this era includes research on racial identity by William E. Cross, Jr. (1971), Janet Helms (1993), Thomas Parham (1989), Joseph White and Thomas Parham (1990), and Marcia Root (1990). The work on providing empirical evidence for the educational benefits of racial diversity (antonio, 2001; Chang, 2002; Hurtado, Carter, \& Kardia, 1998) also belongs in this wave due to 
Journal Committed to Social Change on Race and Ethnicity | 2019

its close reliance on the first wave's comparative studies of Black students' experiences in both historically white and historically Black institutions. Although not developed with higher education contexts specifically in mind, the work of Signithia Fordham and John Ogbu (1986), as well as Michael Omi and Howard Winant (1994), whose work is more often cited by higher education scholars, are significant. These second-wave scholars sought to make sense of the differences among racial groups concerning their experiences and their perceptions of the racial climate in colleges and universities.

Defining characteristics. There are five general characteristics, themes, and ideas professed in this second-wave. First, there is a heavy focus on student (identity) development within the college setting, and that college setting is specifically the fouryear campus. Second, scholars placed race and ethnicity within contexts of oppression but without a critical theoretical engagement of power. This approximates the study of race without racism as discussed by Shaun Harper (2012).

Third, the early emphasis of second-wave race and ethnicity research remained on the Black-white racial binary, although research focused on white identity (Helms, 1993), non-Black People of Color racial and ethnic identities (Kim, 2001; Ferdman \& Gallegos, 2001); Indigenous peoples (Horse, 2001) did come into view. Awareness and acknowledgement of biracial and multiracial identity came through the counseling literature via Maria Root's (1990) scholarship and later in the wave multiraciality was reconsidered by Kris Renn (2000) and Charmaine Wijeyesinghe (2001).

Fourth, as mentioned earlier, a significant body of scholarship was developed during this wave to demonstrate the educational benefits of racially diverse college environments. This scholarship came to be used to defend affirmative action admission 
Journal Committed to Social Change on Race and Ethnicity | 2019

policies in amicae briefs filed in support of the University of Michigan, the University of Texas, and Harvard University. Sociological theories (Cabrera, 2019) define race as a societal construct that is made purposeful - functional even in societal settings. This view could be said to characterize ideas behind the role of race and racial groups as educational benefits in HWls.

Fifth, second-wave literature on race and ethnicity is methodologically bifurcated. The studies of racial and ethnic identity used interpretive paradigms and interviewbased data collection strategies. Studies of the educational benefits of racial diversity were heavily statistically driven.

Resulting effects. Second-wave scholarship on race and ethnicity supported the perpetuation of diversity rhetoric on college and university campuses that discussed race and racial diversity, but not racism as an endemic feature of campus life. This scholarship also contributed to diversifying "whitestream" (Grande, 2004 as cited by Tuck, 2009, p. 56) models of learning, growth, and development. Work by McEwen, Roper, Bryant, and Langa (1990) was instrumental in reshaping whitestream identity development models. Taking on persistence and attrition models, Cabrera, Nora, and Castañeda (1993) introduced compelling statistical studies that challenged the dominant view of Black and Latinx students informed by Tinto's (1987) model first theorized in the 1970s. Cabrera et al. (1993) refuted the idea that students of color needed to assimilate into whiteness in order to succeed and persist in college.

Moreover, the scholarship of this wave led to developmental theory proliferation due to the influx of racial and ethnic identity theories. Scholars of identity development in college focused with increasing specificity on social identities, not solely race and 
Journal Committed to Social Change on Race and Ethnicity | 2019

ethnicity. The expansion of this literature can be traced across the three editions of the

Student Development in College textbook (Evans, Forney, \& Guido-DiBrito, 1998;

Evans, Forney, Guido, Patton, \& Renn, 2009; Patton, Renn, Guido, \& Quaye, 2016).

Finally, this scholarship supported programming efforts by multicultural and identity-based centers. In particular, scholars' earlier emphasis on activism as a key factor in facilitating advanced racial identity development cast center directors and staff in the role of supporting student activism (Shuford, 2011). In these ways, second-wave scholarship built on the first wave by more deeply studying racial identity and refuting the application of models based on white students to BIPOC students.

\section{A Third Wave: Countering Deficit Narratives}

A third wave of research on race and ethnicity in higher education entered in the late 1990 s and crests in the 2000s, somewhat parallel to the rise in public disillusionment with the ineffectiveness of affirmation action policies to end racial inequality in educational access. Within higher education research on race and ethnicity, critical race theory (CRT) and social psychology both are reflected in the canonical scholarship of this third wave, although CRT does not dominate as of yet.

Developed in the 1990s by critical legal scholars, such as Derrick Bell (1995), CRT was taken up by education research generally through the writing of Gloria Ladson-Billings and William Tate (1995). CRT is premised on the recognition that racism is endemic to U.S. society, people are racialized differently within society, various institutional systems and structures interact to compound oppression, and interest convergence (Delgado \& Stefancic, 2017). Although Nolan Cabrera (2018) has asserted that CRT does not have 
Journal Committed to Social Change on Race and Ethnicity | 2019

a theory of race, CRT's central tenets do suggest that critical race theorists understand race to be socially constructed and not biologically inherent.

Scholarship in this era covered a broad terrain, including racial identity, campus climate and institutional services, and college persistence. Racial identity scholarship by Cross and Fhagen-Smith (2001) notably moved away from the linear and hierarchical model of racial identity that Cross first advanced in the 1970s. Other identity-based scholarship considered how social identities beyond race may influence the identity development of racially minoritized students (Patton \& Simmons, 2008; Stewart, 2002, 2009). This scholarship extended the second-wave's focus on extending and complicating singularly-focused whitestream developmental models of race, faith, and gender. Campus climate research by Hurtado, Milem, Clayton-Pedersen, and Allen (1999) was among the first to acknowledge that institutional legacies of inclusion and exclusion based on race had a hand in shaping the campus racial climate. Relatedly, Laura Rendón's (1994) research on validation and mattering put the responsibility on institutions to help minoritized students feel welcome and included on campus. Patton (2010) and Stewart (2011) edited volumes that described and explained the work of identity-based centers and multicultural student services in colleges and universities. Tara Yosso's (2006) community cultural wealth model brought a critical counternarrative approach to college persistence literature. Likewise, much of the race and ethnicity scholarship of this third wave, shifted the responsibility for student learning, growth, and development from fixing the behavior and attitudes of students of color to the practices and policies of historically white institutions. 
Defining characteristics. These illustrations reflect the prevailing characteristics and key themes in third-wave race and ethnicity scholarship by higher education scholars. First, race continued to be treated by scholars as the most salient and orientating social group identity and the foundation from which to begin discussions of diversity on campus. Second, there was a shift in focus from student development as an individual, ego-driven journey to including institutional contexts of racism. Third, scholars took on canonical models and refuted deficit thinking. Fourth, faculty and staff became included as negotiators of racism in higher education and support systems for students of color. This extra labor performed by racially minoritized faculty and staff was discussed earlier by Padilla (1994). Fifth, relatedly, scholarship on racial microaggressions in the counseling literature (Sue et al., 2007) was coupled with William Smith's (2004) introduction of the concept of racial battle fatigue (RBF). Racial microaggressions and RBF became germane to any discussion of the effects of racism on people of color at HWls. Finally, both qualitative and quantitative methodological approaches are represented in the third wave with identity and development studies entirely qualitatively oriented, while climate and persistence studies took quantitative approaches with the exception of Yosso (2006). Despite the growth of CRT in educational research broadly, constructivist and postpositivist paradigms were still prominent in higher education research.

Resulting effects. The effects of third-wave race and ethnicity research by higher education scholars include the growth of campus climate as an area of specific study and focus by institutional administrators. Studies of campus climate grew rapidly as administrators sought ways to develop and sustain harmony on campus among 
Journal Committed to Social Change on Race and Ethnicity | 2019

diverse student groups. Cross and Fhagen-Smith's (2001) research reflected a recognition of the fluidity and shifting meanings of racial identity that would be taken up more fully by race and ethnicity scholars in the fourth wave.

\section{A Fourth Wave: Sociology and CRT}

The first decade of the $21^{\text {st }}$ century closed with the election of the first biracial Black president of the United States, Barack Obama. Much popular rhetoric heralded the election of President Obama and the first Black family to reside in the White House, not as slaves or servants, as evidence of a "post-racial" era in the U.S. (Taylor, 2017, para. 3). Meanwhile, higher education scholarship on race and ethnicity countered that illusion with data illustrating that—at least on U.S. college and university campusesrace, racism, and whiteness were still issues of contention. In light of that consciousness, a fourth wave begins in the 2010 s as sociology and CRT more deeply inform higher education scholars, although some constructivists remain.

Some notable scholarship of this era includes student identity work by Vasti Torres (2003), whose findings demonstrated the ways that immigration and language differentiated the identity development and self-authorship of Latino/a students through a constructivist developmental lens. As an example of the ways that waves overlap, differentiating intragroup experiences is also represented by previously mentioned scholarship by Patton and Simmons (2008), as well as by Harper and Nichols (2008). Susana Muñoz (2018) developed legal consciousness and critical legal consciousness to understand the ways that citizenship status affected Latinx students in college. Other scholarship on racial identity development included that by Johnston-Guerrero (2016), which revisioned racial and ethnic identity development through critical perspectives. 
Journal Committed to Social Change on Race and Ethnicity | 2019

Moving from identity to ideological differences, Liliana Garces and OiYan Poon (2018) have examined differences among Asian Americans related to affirmative action policies in college admissions. The role of minority-serving institutions (MSIs) in shaping the contours of race and ethnicity also emerged with scholarship that delineates what it means to be an Hispanic-serving institution, not just an Hispanic-enrolling one (Garcia, 2019), as well as other work on HBCUs' engagements with the intersections of race and other social identities (Mobley \& Johnson, 2015, 2019).

Defining characteristics. Using mainly qualitative data collection strategies anchored in critical frameworks, scholarship of this wave illustrated five key themes. First, scholars demonstrated that students were agents in their own struggle against racism and settler colonialism (e.g., Muñoz, 2018). Activism reappears as a relevant factor in the experiences of racially minoritized students, not as an identity achievement indicator, but rather as tactics to combat the microaggressions and RBF identified in third-wave scholarship.

Second, the heterogeneity within racial groups discussed by Harper and Nichols (2008), Patton and Simmons (2008), and Torres (2003), as well as that by Chrystal George Mwangi (2014) and Robert Teranishi (2007) became a central focus of identitybased scholarship in this wave. Relatedly, the poststructural idea of performativity, first discussed related to gender by scholars outside of higher education such as Judith Butler (1990), was applied to race and racial identity. Research by Willie (2003) at HBCUs and Stewart (2015) with students at both HWls and HBCUs demonstrated the role of social and intragroup relations in racial identity articulation. 
Journal Committed to Social Change on Race and Ethnicity | 2019

Third, race was recognized as just one among many possibly salient social group identities students held that affected their college experiences (see in addition, Strayhorn, 2013). Also, these scholars examined how racially minoritized students engaged multiple systems and structures of oppression, particularly related to the intersection of race and gender (Patton \& Croom, 2017). Although intersectionality became a common theoretical framework among higher education scholars, it was not always executed consistent with its origins in Black feminism and critical legal studies (Harris \& Patton, 2018). Nevertheless, the recognition that students of color had other social identities that shaped their development and college experiences was important and a necessary evolution from earlier waves.

Fourth, earlier campus climate research centered individual perceptions and intragroup relations, leading institutional leaders to focus on changing and improving those elements. Fourth-wave scholarship on campus climates shifted the focus to acknowledging that institutional systems and structures as articulated in policies and practices were mutually constitutive of campus climate (Chang, Milem, antonio, 2011).

Resulting effects. The resulting effects of this scholarship may actually be the factors that facilitated fourth-wave race and ethnicity research to move in the directions noted above. Other scholars have noted, due in large measure to student activism, the creation of student and faculty advisory boards and chief diversity officer positions in response to student demands (Pettit \& McIntosh, 2011), expansion of responsibilities of multicultural student services offices and leaders (Shuford, 2011), and the need for integrated services that crossed identity groups (Almandrez \& Lee, 2011). Whether these conditions spurred scholars to shift their focus or the shift signaled by fourth-wave 
Journal Committed to Social Change on Race and Ethnicity | 2019

scholarship led to these conditions is difficult to determine. Regardless, the campus landscape for the understanding and engagement with issues of race and ethnicity shifted during the fourth wave.

\section{Lessons from Waves}

These four waves of higher education research on race and ethnicity are neither exhaustive nor mutually exclusive. As discussed earlier, waves overlap and influence each other. Also, the sequencing of these as waves is not meant to suggest that later waves are "better" than earlier ones or that there are not important contributions from each wave. Moreover, there are lessons from these waves that are useful in considering where race and ethnicity scholarship in higher education might lead us.

One lesson is the danger of fixing race and ethnicity as static, immutable constructs. This approach led to the instantiation of racial binaries and erasure of biracial/multiracial lived experiences. This also led to turning the social constructions of racial categories into psychosocial ego identities (Hesse, 2007). Racial categories were created to serve white settler interests in legitimizing racist ideas (Kendi, 2016).

Therefore, making race an aspect of an individual's ego identity serves to legitimate the white supremacist settler colonial state (Hesse, 2007).

Another lesson is the co-optation of higher education research on race and ethnicity to serve institutional interests. For example, scholarship demonstrating the educational benefits of racial diversity were used to prioritize white students' learning and growth over the learning and growth of racially minoritized students. In the interest of serving the multicultural competence and social justice educational needs of majority 
Journal Committed to Social Change on Race and Ethnicity | 2019

white populations at HWls, racially minoritized students were turned into diversity laborers (Quaye, Linder, \& Lange, in press).

Finally, the paradigmatic and methodological bifurcation of higher education scholarship on race and ethnicity has limited opportunities for intra-scholarly conversations among race and ethnicity researchers. The critical orientation of identity development and campus experiences scholarship interpolated through narrative, counternarrative, and case study methodologies is growing. At the same time, hierarchical linear modeling (HLM), structural equation modeling (SEM), and path analysis statistical methodologies have anchored much of the campus climate and educational outcomes research on race and ethnicity. These methods have relied on post-positivist statistical analysis with few critically oriented exceptions (see Teranishi, 2007). Inter-paradigmatic conversations could lead to strengthening scholarship on both sides, especially when projecting implications for policy and practice.

\section{Imagining Possibilities for a Fifth Wave}

I believe that a fifth-wave of higher education scholarship on race and ethnicity is already rippling. This scholarship's disciplinary antecedents are critical ethnic studies, Afrofuturism, Afropessimism, critical whiteness studies, and Indigenous Knowledge Systems. Also, older theoretical frameworks that have been used on a limited basis by higher education scholars are re-emerging, such as Black Feminist Thought (Collins, 1990; see Okello \& White, in press). In these frameworks, race is understood as inherently intersectional (Collins, 1990), as well as mutable, contextual, and temporal (Weheliye, 2014). Moreover, race is understood as (dis)embodied by anti-Blackness and white supremacy (Sharpe, 2016). Importantly, Indigenous scholars have decoupled 
Journal Committed to Social Change on Race and Ethnicity | 2019

race and nationhood in the study of Indigeneity. Although Indigenous peoples are racialized in the U.S. racial hierarchy, they are not a racial group, but rather sovereign nations (Indian Law Resource Center, n.d.) whose experiences in the U.S. are informed by settler colonial white supremacy. Indigenous Knowledge Systems (IKS) are being reclaimed in higher education research (Minthorn \& Shotton, 2018) and used to present findings about Indigenous college students that are rooted in IKS (Shotton, Lowe, \& Waterman, 2013; Waterman, Lowe, \& Shotton, 2018).

A theory of race. Higher education scholarship needs a theory of race (Cabrera, 2018). Race as a performativity, discussed by Dixon-Román (2016), can be thought of similarly to Butler's $(1990,1993)$ discussion of gender identity as "a personal/cultural history of received meanings subject to a set of imitative practices which refer laterally to other imitations and which, jointly, construct the illusion of a primary and interior gendered self" (Butler, 1990, p. 138). Applied to the racialization of groups, individuals are born into meanings of racial group identity that are repeated and reinforced through traditional and ongoing practices that refer to re-membered histories of racial solidity that are then internalized by individual members of racial groups. This process of "sedimentation" (Butler, 1990, p. 178) of racial norms leads to belief in natural, categorizable differences of race. Acknowledging race as a performativity leads to the need to resist "representationalist assumptions" (Dixon-Román, 2016, p. 5). In other words, that race mirrors that to which it refers. Relatedly, race as an assemblage that is situated in events, acts, and situations rather than as characteristics of human subjects is also an extension from research on gender (Puar, 2012). If higher education scholars more deliberately took up such understandings of race and ethnicity, what it 
Journal Committed to Social Change on Race and Ethnicity | 2019

means to be racially minoritized on college campuses could disrupt and complicate racial identifications and support the study of race/racialization in presumably racially monolithic contexts such as HBCUs and Tribal Colleges. The racial context of Hispanic Serving Institutions (HSIs) would also be complicated, to which work by Gina Garcia (2019) is contributing.

Defining characteristics. There are six characteristics of this imagined fifth wave that flow from the incorporation of such critical, post-structural theories of race. First, fifth-wave race and ethnicity scholarship could consider contextual and temporal intrapersonal and interpersonal conceptions, performances, and articulations of race and ethnicity. As Stewart (2017a) has demonstrated, race is not static; its meanings have changed over time. Moreover, student-centered meanings and purposes of being racially minoritized on campus have evolved (Stewart, 2017b). Other historical examinations of campus-based theories of race would be useful to further demonstrate the temporality and contextual nature of race and racial identifications.

Second, fifth-wave race and ethnicity scholarship could consider the role of antiBlackness and settler colonialism as epicenters of discussions of and implications for campus policies and practices regarding race and ethnicity in higher education. How is Blackness used as substitutable, in other words, fungible, for other categories of diversity? The absence/invisibility of Blackness—Black people and/or Black modes of being—is made allowable because of the presence of other (imagined white-dominated) social identity groupings (e.g., disability, sexuality, (trans)gender identity). Moreover, how might such scholarship consider how BIPOC engage in fugitivity, an escape from visibility and assimilationist expectations for diversity engagement on campus? To what 
Journal Committed to Social Change on Race and Ethnicity | 2019

extent are "everyday utopias" (Cooper, 2013) ensconced in spaces (physical and virtual) not visible through campus demographic analyses?

Third, fifth-wave research could decouple and complicate race and nationhood for multiple racialized groups. As noted earlier, such research is already underway regarding Indigenous peoples. Transnational studies of race and ethnicity are needed to further extrapolate the temporality, contextuality, and mutability of race as a category of social difference (see Estera \& Shahjahan, 2018). Essential to such scholarly investigations would be an acknowledgement of the exportation and sedimentation of U.S.-centric ideas of race and ethnicity. Although it is often claimed that race does not "translate" to other national contexts, material outcomes and societal attitudes based on racialized ethnic differences persist in presumably racially monolithic nation-states (see Mullaney, 2011 for discussion of this in China) and those with heavy influxes of Black and Brown immigration (Scott, 2017).

Fourth, fifth-wave race and ethnicity scholarship in higher education could decolonize developmental constructs by decentering the individual and understanding racial identifications as signifiers of being in right relationship with one's community/ies. Fifth-wave scholars must deeply interrogate traditionalist notions of racial identity development founded on increasing competence in navigating white supremacist societal structures-learning to assimilate to oppression (Hesse, 2007). Such an (re)orientation could lead to understanding racial identifications and to strategies for navigating racial oppression as both different from and related to each other. As Michelle Fine (personal communication, April 7, 2019) said in respondent comments at 
Journal Committed to Social Change on Race and Ethnicity | 2019

the American Educational Research Association annual meeting, "We can speak about structures of oppression without forcing people to claim those structures as identities."

Finally, methods of studying race and ethnicity in higher education need to evolve. First, scholars must choose to destabilize and refuse whiteness as the norm for comparison in both statistical and qualitative data. Such practices instantiate [whiteness] —a container for multiple normativities of oppression (Stewart \& Nicolazzo, 2018) - in research and hamper its liberatory outcomes. Second, it becomes vital in this fifth wave to deliberately turn away from self and individually-focused research practices to community-oriented methodologies and methods. This involves decentering individual-centered data collection strategies (the individual interview) to at least accompanying such strategies with ethnographic approaches that place individuals in the context of their broader communities. This would align with understandings of race and ethnicity as temporal, mutable, and contextual. Third, methods in this fifth wave must also embrace polyvocality, allowing for multiple and possibly conflicting understandings of race and ethnicity to emerge from within campus-local communities. Fourth, the integration of community-engaged research methods, such as participatory action research (PAR), would better enable direct, right-now, and community-directed transformations. Fifth, the ontological orientations of fifth-wave race and ethnicity research in higher education would do well to focus on Vizenor's concept of survivance (Vizenor, 2008) and resistance to oppression. Futurity as a paradigmatic orientation would center the possibilities of being within and beyond contexts of oppression.

Implications. Fifth-wave scholarship as described above could have the following implications. Such approaches would disarticulate institutions' abilities to 
transform campus climates and decenter institutions and institutional leaders as the primary drivers for change. As Solange Knowles once tweeted (though later deleted), "[C]reate your own communities, build your own institutions, give your friends awards, award yourself, and be the gold you wanna hold my g's," (Dandridge-Lemco, 2017). Instead, there would be a focus on community-based, both intra- and inter-, strategies and organizing. This would include the development of BIPOC solidarity and rejection of anti-Blackness and white supremacy.

\section{Conclusion}

In this article, I have considered where race and ethnicity research in higher education has been and may currently be. My considerations and categorizations are not meant to be the final word on these waves, what constitutes them, when they begin and end (if they end), and what exemplifies them. However, I do believe this typology to be informative for imagining where we might go in the future of the scholarship of race and ethnicity in postsecondary education. Higher education scholars of race and ethnicity have offered much to the evolving conversation on race and ethnicity in the field. There is much more room for innovation and the possibilities proliferate. I am hopeful that my imaginings may support both established and emerging scholars of race and ethnicity in higher education to surge forward to developing research with communities that has the potential to truly transform the life chances of BIPOC people who face the "brick walls" (Ahmed, 2012, p. 26) of higher education. 


\section{References}

Ahmed, S. (2012). On being included: Racism and diversity in institutional life. Durham, NC: Duke University.

Allen, W. R. (1992). The color of success: African-American college student outcomes at predominantly white and historically Black public colleges and universities. Harvard Educational Review, 62(1), 26-45.

Allen, W. R., \& Jewell, J. O. (2002). A backward glance forward: Past, present, and future perspectives on historically Black colleges and universities. Review of Higher Education, 25, 241-261. http://dx.doi.org/10.1353/rhe.2002.0007

Almandrez, M. G. A., \& Lee, F. J. (2011). Bridging integrated identities to integrated services. In D. L. Stewart (Ed.), Multicultural student services: Building bridges, re-visioning community (pp. 107-123). Sterling, VA: Stylus.

Anderson, J. D. (1993). Race, meritocracy, and the American academy during the immediate post-World War II era. History of Education Quarterly, 33(2), 151-175.

antonio, a. I. (2001). Diversity and the influence of friendship groups in college. Review of Higher Education, 25(1), 63-89.

Bell, D. A. (1995). Who's afraid of critical race theory? University of Illinois Law Review, 1995, 893-910. Retrieved from HeinOnline.

Bonilla-Silva, E. (2006). Racism without racists: Color-blind racism and the persistence of racial inequality in the United States ( $2^{\text {nd }}$ ed.). Lanham, MD: Rowman \& Littlefield.

Butler, J. (1990). Gender trouble: Feminism and the subversion of identity. New York, NY: Routledge.

Butler, J. (1993). Bodies that matter: On the discursive limits of sex. New York, NY: Routledge.

Cabrera, A. F., Nora, A., \& Castenada, M. B. (1993). College persistence: Structural equations modeling test of an integrated model of student retention. Journal of Higher Education, 64(2), 123-139.

Cabrera, N. L. (2018). Where's the racial theory in Critical Race Theory? A constructive criticism of the Crits. Review of Higher Education, 42(1), 209-233.

Cabrera, N. L. (2019, April 6). From individual prejudice to structured racism: Race, whiteness, and critical sociology. Paper presented at the annual meeting of the American Educational Research Association, Toronto, Canada.

Chang, M. J. (2002). Preservation or transformation: Where's the real educational discourse on diversity? Review of Higher Education, 25(2), 125-140.

Chang, M. J., Milem, J. F., \& antonio, a. I. (2011). Campus climate and diversity. In J. H. Schuh, S. R. Jones, \& S. R. Harper (Eds.), Student services: A handbook for the profession ( $5^{\text {th }}$ ed., pp. 43-58). San Francisco, CA: Jossey-Bass.

Collins, P. H. (1990). Black feminist thought: Knowledge, consciousness, and the politics of empowerment. New York, NY: Routledge.

Cooper, D. (2013). Everyday utopias: The conceptual life of promising spaces. Durham, NC: Duke University.

Crenshaw, K. W. (1991). Mapping the margins: Intersectionality, identity politics, and violence against women of color. Stanford Law Review, 43(6), 1241-1299.

Cross, W. E., Jr. (1971). Toward a psychology of Black liberation: The Negro-to-Black conversion experience. Black World, 20(9), 13-27. 
Cross, W. E., Jr., \& Fhagen-Smith, P. (2001). Patterns of African American identity development: A life span perspective. In C. L. Wijeyesinghe \& B. W. Jackson (Eds.), New perspectives on racial identity development: A theoretical and practical anthology (pp. 243-270). New York: New York University.

Dandridge-Lemco, B. (2017, February 13). Solange on the Grammy's: "Create your own committees, build your own institutions." The Fader.com. Available at https://www.thefader.com/2017/02/13/solange-grammys-response-beyoncelemonade

Delgado, R., Stefancic, J. (2017). Critical race theory: An introduction ( $3^{\text {rd }}$ ed.). New York: New York University.

Dixon-Román, E. J. (2016). Diffracting enfolding futures: Critical inquiry in quantitative educational research. Critical Education, 7(14), 1-23. https://doi.org/10.14288/ce.v7i14.186147

Estera, A., \& Shahjahan, R. A. (2018). Globalizing whiteness? Visually re/presenting students in global university rankings websites. Discourse: Studies in Cultural Politics of Education, DOI: 10.1080/01596306.2018.1453781

Evans, N. J., Forney, D. S., \& Guido-DiBrito, F. (1998). Student development in college: Theory, research, and practice (1 $1^{\text {st }}$ ed.). San Francisco, CA: Jossey-Bass.

Evans, N. J., Forney, D. S., Guido, F., Patton, L. D., \& Renn, K. A. (2009). Student development in college: Theory, research, and practice ( $\left.2^{\text {nd }} \mathrm{ed}.\right)$. San Francisco, CA: Jossey-Bass.

Feagin, J. R., Vera, H., \& Imani, N. (1996). Agony of education: Black students at white colleges and universities. New York, NY: Routledge.

Ferdman, B. M., \& Gallegos, P. I. (2001). Racial identity development and Latinos in the United States. In C. L. Wijeyesinghe \& B. W. Jackson (Eds.), New perspectives on racial identity development: A theoretical and practical anthology (pp. 32-66). New York: New York University.

Fleming, J. (1984). Blacks in college: A comparative study of students' success in Black and in white institutions. San Francisco, CA: Jossey-Bass.

Fordham, S., \& Ogbu, J. U. (1986). Black students' school success: Coping with the "burden of 'acting white." The Urban Review, 18(3), 176-206.

Garces, L., \& Poon, O. (2018, November 1). Asian Americans and race-conscious admissions: Understanding the conservative opposition's strategy of misinformation, intimidation, and racial division. Civil Rights Project. Los Angeles: University of California. Available at https://www.civilrightsproject.ucla.edu/research/college-access/affirmativeaction/asian-americans-and-race-conscious-admissions-understanding-theconservative-opposition2019s-strategy-of-misinformation-intimidation-racialdivision/RaceCon GarcesPoon AsianAmericansRaceConsciousAdmi.pdf

Garcia, G. A. (2019). Becoming Hispanic-serving institutions: Opportunities for colleges and universities. Baltimore, MD: Johns Hopkins University.

George Mwangi, C. A. (2014). Complicating blackness: Black immigrants and racial positioning in U.S. higher education. Journal of Critical Thought and Praxis, 3(2). https://doi.org/10.31274/jctp-180810-41

Grande, S. (2004). Red pedagogy: Native American social and political thought. Lanham, MD: Rowman \& Littlefield. 
Harper, S. R. (2012). Race without racism: How higher education researchers minimize racist institutional norms. Review of Higher Education, 36(1), Supplement, 9-29.

Harper, S. R., \& Nichols, A. H. (2008). Are they not all the same? Racial heterogeneity among Black male undergraduates. Journal of College Student Development, 49(3), 247-269.

Harris, J. C., \& Patton, L. D. (2018). Un/doing intersectionality through higher education research [Online First Publication]. The Journal of Higher Education. https://doi.org/10.1080/00221546.2018.1536936

Helms, J. E. (1993). Toward a model of white racial identity development. In J. E. Helms (Ed.), Black and white racial identity: Theory, research, and practice (pp. 49-66). Westport, CT: Praeger.

Hesse, B. (2007). Racialized modernity: An analytics of white mythologies. Ethnic and Racial Studies, 30(4), 643-663.

Horse, P. G. (2001). Reflections on American Indian identity. In C. L. Wijeyesinghe \& B. W. Jackson (Eds.), New perspectives on racial identity development: $A$ theoretical and practical anthology (pp. 91-107). New York: New York University Press.

Hurtado, A. (2019, April 6). "Race" in search of a discipline. Paper presented at the annual meeting of the American Educational Research Association, Toronto, Canada.

Hurtado, S., Carter, D. F., \& Kardia, D. (1998). The climate for diversity: Key issues for institutional self-study. New Directions for Institutional Research, no. 98 (pp. 5363). San Francisco, CA: Wiley.

Hurtado, S., Milem, J., Clayton-Pedersen, A., Allen, W. R. (1999). Enacting diverse learning environments: Improving the climate for racial/ethnic diversity in higher education. ASHE-ERIC Higher Education Report, 26(8). Washington, DC: ERIC Clearinghouse.

Indian Law Resource Center. (n.d.). Tribes are governments, not racial classifications. Available at https://indianlaw.org/story/tribes-are-governments-not-racialclassifications

Johnston-Guerrero, M. P. (2016). Embracing the messiness: Critical and diverse perspectives. In E. S. Abes (Ed.), Critical perspectives on student development theory (pp. 43-56). New Directions for Student Services, no. 154. San Francisco, CA: Wiley.

Jones, S. R., \& Stewart, D.-L. (2016). Evolution of student development theory. In E. S. Abes (Ed.), Critical perspectives on student development theory (pp. 17-28). New Directions for Student Services, no. 154. San Francisco, CA: Wiley.

Kendi, I. X. (2016). Stamped from the beginning: The definitive history of racist ideas in America. New York, NY: Nation Books.

Kim, J. (2001). Asian American identity development theory. In C. L. Wijeyesinghe \& B. W. Jackson (Eds.), New perspectives on racial identity development: $A$ theoretical and practical anthology (pp. 67-90). New York: New York University.

Ladson-Billings, G., \& Tate, W. F., IV. (1995). Toward a critical race theory of education. Teachers College Record, 97(1), 47-68. 
McEwen, M. K., Roper, L. D., Bryant, D. R., \& Langa, M. J. (1990). Incorporating the development of African-American students into psychosocial theories of student development. Journal of College Student Development, 31, 429-436.

Mobley, S. D., Jr., \& Johnson, J. M. (2015). The role of HBCUs in addressing the unique needs of LGBT students. In R. T. Palmer, C. R. Shorette II, \& M. Gasman (Eds.), Exploring diversity at historically Black colleges and universities: Implications for policy and practice (pp. 79-89). New Directions for Higher Education, 170. San Francisco, CA: Wiley.

Mobley, S. D., Jr., \& Johnson, J. M. (2019). "No pumps allowed": The "problem" with gender expression and the Morehouse College "appropriate attire policy." Journal of Homosexuality, 66(7), 867-895.

Minthorn, R. S., \& Shotton, H. J. (2018). Reclaiming Indigenous research in higher education. New Brunswick, NJ: Rutgers University.

Mullaney, T. S. (2011). Coming to terms with the nation: Ethnic classification in modern China. Berkeley: University of California.

Muñoz, S. M. (2018). Unpacking legality through La Facultad and cultural citizenship: Critical and legal consciousness formation for politicized Latinx undocumented youth activists. Equity and Excellence in Education, 51, 78-91.

Okello, W. K., \& White, K. (in press). A Black feminist reconstruction of agency. In E. S. Abes, S. R. Jones, \& D-L. Stewart (Eds.), Rethinking college student development theory through critical perspectives. Sterling, VA: Stylus.

Omi, M., \& Winant, H. (1994). Racial formation in the United States: From the 1960s to the 1990 s $\left(2^{\text {nd }}\right.$ ed.). New York, NY: Routledge.

Padilla, A. M. (1994). Ethnic minority scholars, research, and mentoring: Current and future issues. Educational Researcher, 23(4), 24-27.

Patton, L. D. (Ed.). (2010). Culture centers in higher education: Perspectives on identity, theory, and practice. Sterling, VA: Stylus.

Patton, L. D., \& Croom. N. N. (Eds.). (2017). Critical perspectives on Black women and college success. New York, NY: Routledge.

Patton, L. D., Renn, K. A., Guido, F., \& Quaye, S. J. (2016). Student development in college: Theory, research, and practice ( ${ }^{\text {rd }}$ ed.). San Francisco, CA: JosseyBass.

Patton, L. D., \& Simmons, S. (2008). Exploring complexities of multiple identities of lesbians in a Black college environment. Negro Educational Review, 59(3-4), 197-215.

Parham, T. (1989). Cycles of psychological nigrescence. The Counseling Psychologist, $17(2), 187-226$.

Perez Huber, L. (2010). Using Latina/o critical race theory (LatCrit) and racist nativism to explore intersectionality in the educational experiences of undocumented Chicana college students. Educational Foundations, 24(1-2), 77-96.

Pettit, B., \& McIntosh, D. (2011). Negotiating purpose and context. In D. L. Stewart (Ed.), Multicultural student services on campus: Building bridges, re-visioning community (pp. 201-217). Sterling, VA: Stylus.

Plaut, R. L. (1954). Racial integration in higher education in the North. The Journal of Negro Education, 23, 310-316. 
Puar, J. K. (2012). "I would rather be a cyborg than a goddess": Becoming-intersectional in assemblage theory. philoSOPHIA, 2(1), 49-66.

Quaye, S. J., Linder, C., \& Lange, A. (in press). "A student should have the privilege of just being a student": Student activism as labor. Review of Higher Education [Special Issue].

Rendon, L. I. (1994). Validating culturally diverse students: Toward a new model of learning and student development. Innovative Higher Education, 19(1), 33-51.

Renn, K. A. (2000). Patterns of situational identity among biracial and multiracial college students. Review of Higher Education, 23(4), 399-420.

Root, M. P. P. (1990). Resolving "other" status: Identity development of biracial individuals. In L. S. Brown \& M. P. P. Root (Eds.), Complexity and diversity in feminist theory and therapy (pp. 185-205). New York, NY: Haworth Press.

Salinas, C., \& Lozano, A. (2017). Mapping and recontextualizing the evolution of the term Latinx: An environmental scanning in higher education. Journal of Latinos and Education, 1-14. https://doi.org/10.1080/15348431.2017.1390464

Scott, J. W. (2017, September 20). The culture veil: The real crisis of European multiculturalism. The Nation. Available at https://www.thenation.com/article/theculture-veil/

Sharpe, C. (2016). In the wake: On blackness and being. Durham, NC: Duke University. Shotton, H. J., Lowe, S. C., \& Waterman, S. J. (2013). Beyond the asterisk: Understanding Native students in higher education. Sterling, VA: Stylus.

Shuford, B. C. (2011). Historical and philosophical development of multicultural student services. In D. L. Stewart (Ed.), Multicultural student services on campus: Building bridges, re-visioning community (pp. 29-37). Sterling, VA: Stylus.

Smith, W. A. (2004). Black faculty coping with racial battle fatigue: The campus racial climate in the post-civil rights era. In D. Cleveland (Ed.), A long way to go: Conversations about race by African American faculty and graduate students (pp. 171-190). New York, NY: Peter Lang.

Stewart, D. L. (2002). The role of faith in the development of an integrated identity: A qualitative study of Black students at a white college. Journal of College Student Development, 43(4), 579-596.

Stewart, D. L. (2009). Perceptions of multiple identities among Black college students. Journal of College Student Development, 50(3), 253-270.

Stewart, D. L. (Ed.). (2011). Multicultural student services: Building bridges, re-visioning community. Sterling, VA: Stylus.

Stewart, D.-L. (2015). Know your role: Black college students, racial identity, and performance. International Journal of Qualitative Studies in Education, 28(2), 238-258.

Stewart, D.-L. (2017a). Race and historiography: Advancing a critical-realist approach. Journal of Diversity in Higher Education, 10(2), 149-161.

Stewart, D.-L. (2017b). Black collegians' experiences in U.S. northern private colleges. New York, NY: Springer.

Stewart, D.-L., \& Nicolazzo, Z. (2018). The high impact of [whiteness] on trans* students in postsecondary education. Equity \& Excellence in Education, 51(2), 132-145.

Strayhorn, T. L. (Ed.). (2013). Living at the intersections: Social identities and Black collegians. Charlotte, NC: Information Age Publishing. 
Sue, D. W., Capodilupo, C. M., Torino, G. C., Bucceri, J. M., Holder, A. M. B...., \& Esquilin, M. (2007). Racial microaggressions in everyday life: Implications for clinical practice. American Psychologist, 62(4), 271-286.

Taylor, K.-Y. (2017, January 13). Barack Obama's original sin: America's post-racial illusion. The Guardian. Available at https://www.theguardian.com/usnews/2017/jan/13/barack-obama-legacy-racism-criminal-justice-system

Teranishi, R. (2007). Race, ethnicity, and higher education policy: The use of critical quantitative research. New Directions for Institutional Research, no. 133, 37-49. San Francisco, CA: Wiley.

Tinto, V. (1987). Leaving college. Chicago, IL: University of Chicago.

Torres, V. (2003). Influences on ethnic identity development of Latino college students in the first two years of college. Journal of College Student Development, 44(4), 532-547.

Tuck, E. (2009). Re-visioning action: Participatory action research and Indigenous theories of change. Urban Review, 41, 47-65.

Vizenor, G. (2008). Survivance: Narratives of Native presence. Lincoln: University of Nebraska.

Warren, J. (2019, April 6). The roots of U.S. anthropology's race problem: Whiteness, ethnicity, and ethnography. Paper presented at the annual meeting of the American Educational Research Association, Toronto, Canada.

Waterman, S. J., Lowe, S. C., \& Shotton, H. J. (2018). Beyond access: Indigenizing programs for Native student success. Sterling, VA: Stylus.

Weheliye, A. G. (2014). Habeas viscus: Racializing assemblages, biopolitics, and Black feminist theories of the human. Durham, NC: Duke University.

White, J. L, \& Parham, T. A. (1990). The psychology of Blacks: An African-American perspective $\left(2^{\text {nd }}\right.$ ed.). Upper Saddle River, NJ: Prentice Hall.

Wijeyesinghe, C. L. (2001). Racial identity in multiracial people: An alternative paradigm. In C. L. Wijeyesinghe \& B. W. Jackson (Eds.), New perspectives on racial identity development: $A$ theoretical and practical anthology (pp. 129-152). New York: New York University Press.

Willie, S. S. (2003). Acting black. New York, NY: Routledge.

Yosso, T. J. (2006). Whose culture has capital? A critical race theory discussion of community cultural wealth. Race, Ethnicity, and Education, 8(1), 69-91.

Zimbardo, P. G. (1966). Physical integration and social segregation of northern Negro college students. Paper presented at Eastern Psychological Association conference. ERIC document retrieval service no. ED 025568.

Zuroski, E. (2018, September 16). "Yes-we've adopted BIPoC to include all categories of racialized peoples, but to acknowledge the specific forms of racism and colonialism particular to Black and Indigenous communities. And since the long C18 saw the cultivation of so many of these racisms," [Twitter post]. Available at https://twitter.com/zugenia/status/1041340608298799104 